\title{
Observing the Middle Elbe Biosphere in Germany by Means of TerraSAR-X Images
}

\author{
Dalia Farghaly, Emad Elba, Brigitte Urban \\ Faculty of Sustainability Sciences, Institute of Ecology, Division of Landscape Change, \\ Leuphana University of Lüneburg, Lüneburg, Germany \\ Email: dalia.farghaly@stud.leuphana.de
}

Received January 1, 2014; revised January 31, 2014; accepted February 17, 2014

Copyright (c) 2014 Dalia Farghaly et al. This is an open access article distributed under the Creative Commons Attribution License, which permits unrestricted use, distribution, and reproduction in any medium, provided the original work is properly cited. In accordance of the Creative Commons Attribution License all Copyrights (c) 2014 are reserved for SCIRP and the owner of the intellectual property Dalia Farghaly et al. All Copyright (C) 2014 are guarded by law and by SCIRP as a guardian.

\begin{abstract}
The Lower Saxonian Elbe Valley Biosphere Reserve is part of the UNESCO Biosphere Reserve "Elbe River Landscape", and used mainly for agriculture. One of tasks of the Biosphere Reserve Administration is to develop sustainable forms of land use which requires comprehensive updated land cover maps. Land use maps are hard to produce because of surveying costs and time. Nevertheless, these large areas need to be monitored. TerraSAR-X images are used to establish agricultural land use maps. In this study, two areas are selected within the Elbe Biosphere Reserve situated around the oxbows Wehninger Werder and Walmsburger Werder. Multi temporal classification methods were used to identify the different crops using maximum likelihood classifier for the years 2010 and 2011. The crop classifications were used to evaluate the effect of the number of images, the necessity of polarizations, and the consequences of some missing images within the crop calendar. These classifications were analyzed to estimate producer accuracy and Kappa index for each crop besides the overall accuracy for each agricultural land use map. The study shows that using dual polarization imagery enhances producer accuracies for many crops over the single polarization imagery, and demonstrates the importance of using frequent images during the cultivation period.
\end{abstract}

\section{KEYWORDS}

Agricultural Land Use; Elbe River; Multi Temporal Classification; TerraSAR-X; UNESCO Biosphere Reserves

\section{Introduction}

As a part of the UNESCO Biosphere Reserve "Flusslandschaft Elbe" (Elbe River Landscape) the floodplains of the Lower Saxonian Elbe Valley are representative of one of the largest European river landscapes as shown in Figure 1. Elbe River is the fourth largest river basin in Europe, after the Danube, the Visla, and the Rhine. The Elbe River flows through four countries namely Germany, the Czech Republic, Austria and Poland. 65\% of the river basin lies in Germany [1]. The Elbe River Landscape Reserve has a total area of $3430 \mathrm{~km}^{2}$ and stretches along 400 kilometers of the course of the Elbe River. As a UNESCO Biosphere Reserve it is a model region for sustainable development, which aims to achieve a balance between the interests of environmental protection and of social and economic development. It promotes environmentally-friendly agriculture, regional marketing, low-impact tourism, and an educational program for sustainable development (ESD), including research and monitoring activities [2]. Within Germany as a whole, the biosphere reserves cover almost $3 \%$ of the land area, including 15 territories designated as UNESCO biosphere reserves. They represent vital habitats, the diversity of fauna and flora, typical landscapes including mainly farm land located in the rural areas and cultivated at different levels of intensity as stated on the UNESCO website

http://www.unesco.org/new/en/natural-sciences/environ ment/ecological-sciences/biosphere-reserves/.

The Elbe River Biosphere Reserve in Lower Saxony reaches from Schnackenburg in the south-east at Elbe-km 472.5 to Hohnstorf in the north-west at Elbe-km 569. The Elbe River kilometrage starts with zero at the Czech-Ger- 


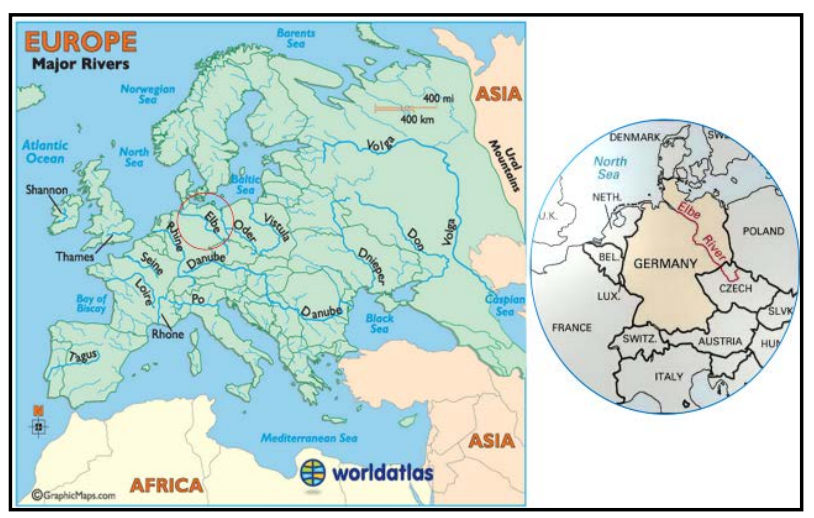

Figure 1. Major Rivers in Europe and the Elbe basin [1].

man state border, the numbers grow in the upstream direction on the Czech side, as well as in the downstream direction on the German side [1]. The terrain of the reserve ranges from $5 \mathrm{~m}$ to $109 \mathrm{~m}$ above mean sea level. It covers a total area of about 570 square kilometers. As a historically cultural landscape the floodplains are used in various ways with a predominance of agricultural land use [3]. The variation in the current land uses is shown in Figure 2. A big division of $68 \%$ is covered with agricultural fields and grassland areas. Numerous researchers have reflected on land use effects on the environment [4-6]. Regions around rivers, mainly the biosphere areas, must be monitored to avoid environmental problems that might affect the multiple ecological, economic and social functions of those areas [7]. Pasture land situated in the recent flood plain is affected by contaminated suspended sediment loads deposited during flooding which can cause soil, crop, and fodder pollution [8]. On the other hand arable land is a possible source for groundwater and soil pollution. This floodplain has suffered from major flooding such as the 2002 flood, which caused huge damage in hazardous areas of the Elbe catchment. Thus many studies have been conducted to improve flood risk management schemes for the Elbe basin [9-11].

Planning the development of sustainable forms of land use, the Biosphere Reserve Administration "Niedersächsische Elbtalaue" requires updated, comprehensive maps. Surveying costs and time make it difficult to produce land use maps in the field [12]. As an alternative, satellite images can be used to provide the necessary information. As countries in Europe are usually covered with clouds, RADAR images are widely used to overcome weather problems. These images attest to be functional in generating land cover maps [13]. One of the most recent effective image types is TerraSAR-X images (TSX) acquired by the German Earth observation satellite, laun- ched 15 June 2007. It flies over the same location every 11 days. It uses an X-band SAR with $31 \mathrm{~mm}$ wavelength and 9.6 $\mathrm{GHz}$ frequency providing high-quality topographic information for commercial and scientific applications

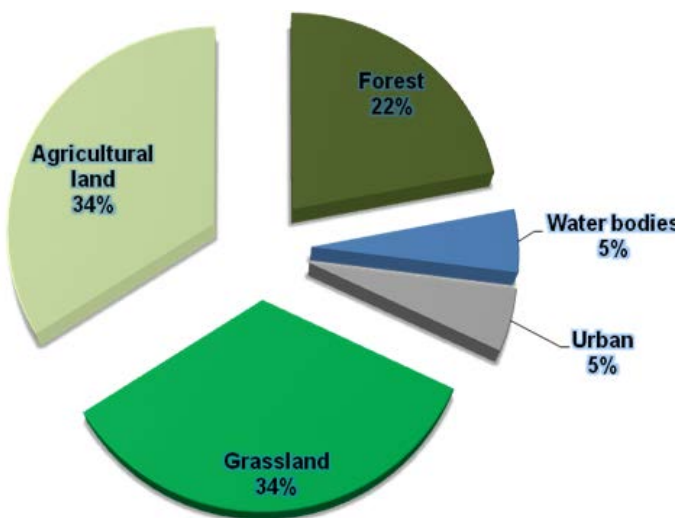

Figure 2. Distribution of land use and land cover in the Elbe River Biosphere Reserve in Lower Saxony. Source: UNESCO website

http://www.unesco.org/new/en/natural-sciences/environmen t/ecological-sciences/biosphere-reserves.

as stated on DLR website:

http://www.dlr.de/eo/en/Portaldata/64/Resources/dokument e/TSX brosch.pdf. Farghaly et al. showed the effectiveness of TSX images in distinguishing between aquatic weed types over lake Kyoga [14]. Lohmann et al. also demonstrated the efficiency of these images in determining the different types of crops within agricultural fields near Hanover, Lower Saxony [15].

Previous studies investigated crop production and land use maps using ENVISAT imagery. Some studies recommended the use of an appropriate range of images within a time series according to the crop-calendar, to achieve better classification results than using all of the images [16]. Many fields are cultivated by more than one type of crop during the year. Thus, such succession is difficult to model because it is controlled by phenological and ecological courses. Tavakkoli et al. show that using all of the images without considering the crop calendar resulted in less producer accuracy [17]. ENVISAT images have a C-band signal which passes partially through vegetation cover. This might lead to classification errors where the signals are influenced by the soil surface under the vegetation cover [18]. Thus some studies recommend using higher frequency signals such as $\mathrm{X}$-band where the signals are more reflected by the vegetation cover [16]. This enables better crop classification results where the classification process identifies patterns of similar characteristics according to the corresponding observed backscattering response and their temporal progress.

This study identifies the agricultural land uses within two study areas. These areas are located within the Lower Saxonian "Elbe River Valley Meadows" Biosphere Reserve in Germany, around two oxbows the Wehninger Werder, and Walmsburger Werder (Werder $=$ oxbow $)$ as shown in Figure 3. Spotlight TerraSAR-X images in dual polarization $(\mathrm{HH}, \mathrm{VV})$ are used to monitor the two 


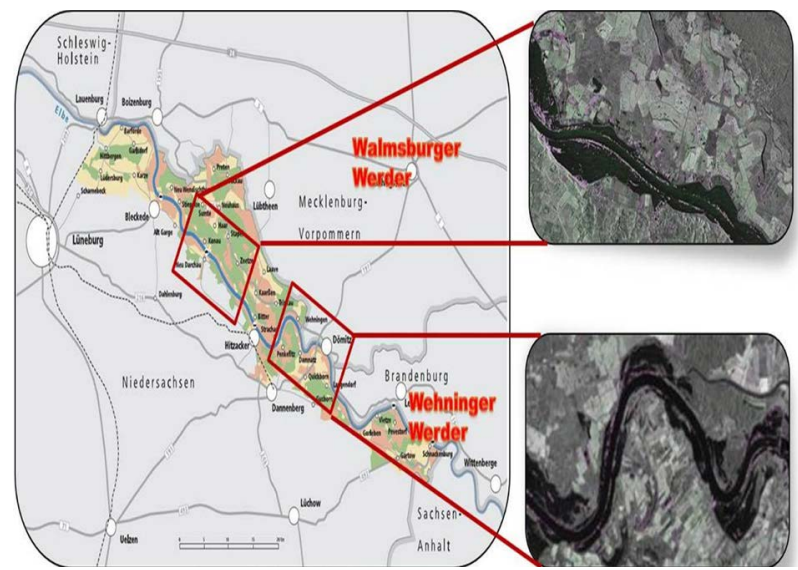

Figure 3. Location of study areas within the Lower Saxonian Elbe River Biosphere Reserve.

areas. HH means horizontal transmit and horizontal receive, while VV means vertical transmit and vertical receive. The images are used to produce several proper classifications which identify the crops cultivated in the investigated areas based on the field visits. The produced classifications are analyzed to evaluate the parameters which affect the producer accuracy of each crop in particular: polarization type, the number of manipulated images, image regularity, filter type, maintaining crop calendar, and the size of surveyed fields. The surveyed areas are large accessible fields. 50\% of the surveyed area is considered as test fields. The test fields are assumed to be remote inaccessible areas.

\section{Methods and Materials}

\subsection{Study Area}

Two study areas are selected around the Wehninger Werder between Elbe-Kilometer (505 - 520), and Walmsburger Werder between Elbe-Kilometer (533 - 543) within the Lower Saxonian Elbe River Biosphere Reserve (Figure 3). Both areas are bearing several types of land use including urban and rural regions with agricultural land use dominant. The river floodplain produces high quality hay. Thus usually these meadows are mown once or twice a year, depending not only on weather conditions and flood events, but also on the Biosphere Reserve regulations to protect the fauna and flora within this particular environment [19]. The produced hay is used for feeding livestock if it is not contaminated or for Biogas production if it is contaminated [20]. 30\% of this area is covered by forests, which must be maintained to ensure the sustainability of the flood plain environment. Over $65 \%$ of this area is covered by agricultural fields and grasslands which are considered the main possible sources of environmental pollution as well as they are possible sinks for flood borne contaminations. This study therefore focuses on this part of the Biosphere Reserve.

\subsection{Data Collection}

The used TSX images were acquired within the period from March 2010 to November 2011 as listed in Table 1. The images are Dual Polarization Spotlight Products. They are high resolution spatially enhanced images with a descending angle of $40^{\circ}$ which leads to higher range and azimuth pixel spacing of $1 \mathrm{~m}$. The incidence angle of $25^{\circ}$ enables only $1.5 \mathrm{~m}$ range and azimuth pixel spacing. It was planned for this study to acquire images each 22 days, however, due to some operational reasons, some images could not be taken. Over Walmsburger Werder, there was a great gap of 66 days in 2010 during the growing period of most of the crops cultivated there, while in 2011 there were two gaps of 44 days. Over Wehninger Werder, the images had no gaps.

The accessible fields covered by these images were surveyed to determine the crops cultivated there. In year 2010, the fields were visited once in June. About 50 fields were surveyed around Walmsburger Werder. In year 2011, field visits were conducted monthly to several reachable and representative areas on similar dates to the acquisition times. Previous research had recommended surveying a greater number of fields in order to increase the validity of the obtained preliminary results [21]. Therefore, more than 150 fields were visited around Walmsburger Werder totaling 1550 hectares representative of $80 \%$ of the arable land within this area. In addition, about 300 fields were investigated around Wehninger Werder covering about 1860 hectares representing 70\% of the arable land. Major crops cultivated during the period from March to October were barley, wheat, rye, rye-grass, maize, potato, sugar-beet root, rapeseed, and sunflower. Rye, wheat and barley have similar texture which causes similar back scatter values over the radar images; hence they are grouped together in the cate

Table 1. List of acquired images and calendar date of land investigations.

\begin{tabular}{|c|c|c|c|c|}
\hline \multirow{2}{*}{ No } & \multicolumn{2}{|c|}{ Walmsburger Werder } & \multirow{2}{*}{$\begin{array}{l}\text { Wehninger } \\
\text { Werder } 2011\end{array}$} & \multirow{2}{*}{$\begin{array}{l}\text { Ground } \\
\text { Truth } \\
\text { Date }\end{array}$} \\
\hline & 2010 & 2011 & & \\
\hline 1 & ------ & $26^{\text {th }}$ March & ----- & \\
\hline 2 & $30^{\text {th }}$ April & $17^{\text {th }}$ April & ------ & \\
\hline 3 & ------ & ------ & & \\
\hline 4 & ------ & $31^{\text {st }}$ May & $6^{\text {th }}$ June & June \\
\hline 5 & $5^{\text {th }}$ July & $22^{\text {nd }}$ June & $28^{\text {th }}$ June & \\
\hline 6 & $27^{\text {th }}$ July & ------ & $20^{\text {th }}$ July & July \\
\hline 7 & $18^{\text {th }}$ August & $5^{\text {th }}$ August & $11^{\text {th }}$ August & August \\
\hline 8 & $9^{\text {th }}$ September & $27^{\text {th }}$ August & $2^{\text {nd }}$ September & \\
\hline 9 & ------ & $18^{\text {th }}$ September & $24^{\text {th }}$ September & September \\
\hline 10 & $23^{\text {rd }}$ October & $10^{\text {th }}$ October & $16^{\text {th }}$ October & October \\
\hline 11 & $14^{\text {th }}$ November & $1^{\text {st }}$ November & $7^{\text {th }}$ November & \\
\hline
\end{tabular}


gory of cereals. Grass is harvested for animal feed or used as pasture land, and is considered as one of the crops and called grassland. In 2010, the agricultural land use classifications were generated for 6 types of crops including grassland. In 2011, classifications were conducted for 7 crops beside the grassland. The fields were divided into training fields group which were used as reference data, and a testing fields group which were used for assessing the accuracy of the produced classifications. These test fields were assumed as remote in inaccessible areas to test the possibility of considering the classification of the real remote areas. The list of the number of investigated fields for each crop and the number of the training fields, and the testing fields is presented in Table 2. The spatial allocation of these fields is shown in Figure 4.

\subsection{Image Processing}

TerraSAR-X images are known for speckle noise problems which affect the accuracy of classification results [18]. These speckle noises are due to coherent superposition of multiple backscatter sources. Therefore, speckle reduction must be applied to the images in order to remove the speckle noise. The TSX images must be filtered in order to remove or decrease these noises to permit better discrimination of scene targets [22]. Lee filter is an adaptive filter which is based on the assumption that the mean and variance of the pixel of interest are

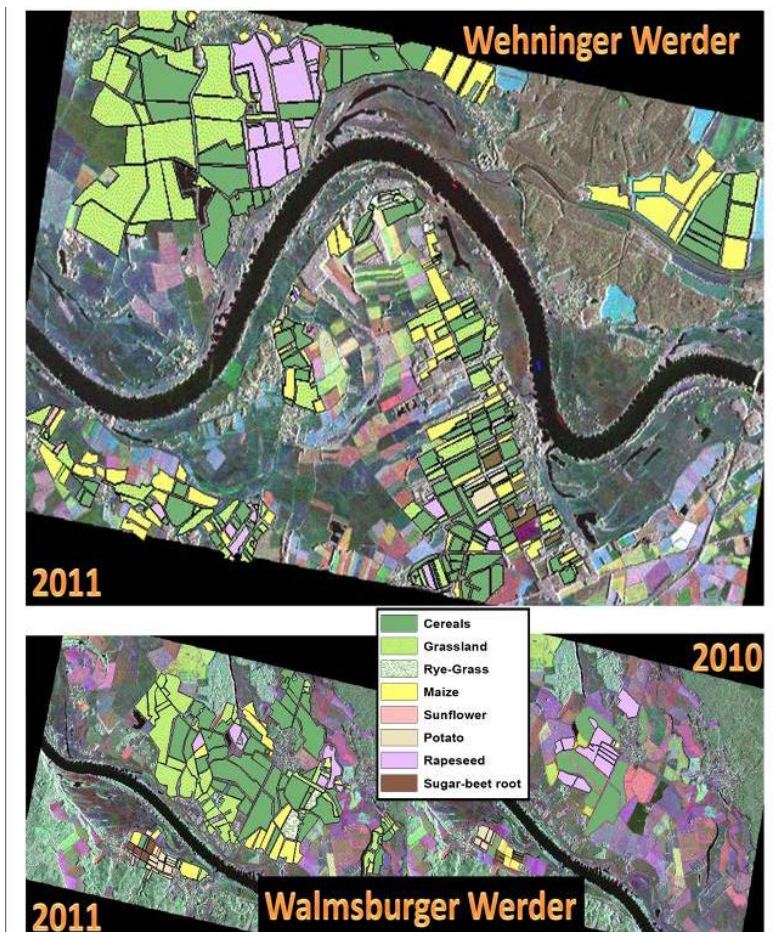

Figure 4. Distribution of different crops over the inspected fields around Walmsburger and Wehninger Werder.
Table 2. List of crop types and number of used fields in testing the classification results.

\begin{tabular}{|c|c|c|c|c|c|c|c|c|c|c|}
\hline \multirow{3}{*}{ Crop Type } & \multirow{3}{*}{$\begin{array}{c}\text { Cultivation } \\
\text { period }\end{array}$} & \multirow{2}{*}{\multicolumn{3}{|c|}{$\begin{array}{c}\text { Survey } 2010 \\
\begin{array}{c}\text { Walmsburger } \\
\text { Werder }\end{array}\end{array}$}} & \multicolumn{6}{|c|}{ Survey 2011} \\
\hline & & & & & \multicolumn{4}{|c|}{$\begin{array}{c}\text { Walmsburger } \\
\text { Werder }\end{array}$} & \multicolumn{2}{|c|}{$\begin{array}{l}\text { Wehninger } \\
\text { Werder }\end{array}$} \\
\hline & & 哭 & $\stackrel{\mathscr{E}}{\oplus}$ & 쥽 & 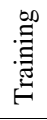 & $\stackrel{\mathscr{E}}{\uplus}$ & 矛 & 祖 & $\stackrel{\tilde{2}}{\oplus}$ & స్ㅠำ \\
\hline & & 4 & 0 & 10 & 17 & 30 & 47 & 46 & 60 & 106 \\
\hline Rye-grass & Mar.-Aug. & 0 & 0 & $\mathbf{0}$ & 1 & 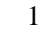 & 2 & 1 & 1 & 2 \\
\hline Grassland & Mar.-Nov. & 1 & 2 & 3 & 21 & 33 & 54 & 29 & 43 & 72 \\
\hline Maize & May-Nov. & 4 & 6 & 10 & 9 & 10 & 19 & 36 & 43 & 79 \\
\hline Sunflower & Mar.-Nov. & 0 & 0 & $\mathbf{0}$ & 4 & 0 & 10 & 1 & 1 & 2 \\
\hline Potato & Mar.-Sep. & 3 & 3 & 6 & 5 & 11 & 16 & 2 & 3 & 5 \\
\hline Rapeseed & Mar-Aug. & 5 & 7 & 12 & 3 & 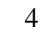 & 7 & 9 & 21 & 30 \\
\hline Sugar-beet & Mar.-Oct. & 3 & 3 & 6 & 2 & 2 & 4 & 2 & 2 & 4 \\
\hline Total & & 20 & 27 & 47 & 62 & 97 & 159 & 126 & 174 & 300 \\
\hline
\end{tabular}

equal to the local mean and variance of all pixels within the moving window. This preserves image sharpness and details while suppressing noise [23,24]. Many images of the same location are taken at different frequent dates. Thus, multi-temporal speckle filtering is applied to exploit the space-varying temporal correlation of speckle between the images, which reduces the system inherent multiplicative noise. The De-Grandi filter is an optimum weighting filter which was introduced to balance differences in reflectivity between images at different times. This enhances the image sharpness and enables identifying more details [25].

For both study areas, the images with both their acquisitions were coregistered to correct for relative translational shift and rotational and scale differences through performing spatial registration and potentially resampling. This was done using SARSCAPE module of the ENVI program after importing them as TerraSAR-X standard formats. The coregistered images were geocoded to provide a radiometric calibration and a cartographic reference system. The images were filtered in order to remove or decrease the speckle noise using Lee and Degrandi filter as mentioned before. The lee filter was applied using ERDAS imagine software through the Speckle Suppression option under Radar Interpreter menu. The coefficient of variation for the subset of the geocoded images was calculated for each image. The Lee filter was selected from the list of available filters and the coefficient of variation value was inserted. The window size was set to 7 pixels. The filtered images were stacked together to have one image consisting of 14 layers presenting 7 dates in both $\mathrm{VV}$ and $\mathrm{HH}$ polarization for Walmsburger Werder in 2010, and 18 layers presenting 9 dates in 2011, in addition to 16 layers presenting 8 dates for Wehninger 
Werder in 2011. The effect of using Lee filter on the image sharpness is shown in Figure 4. The De-Grandi Filter was applied using SARSCAPE Module under ENVI program on the coregistered images. The resulted filtered images were stacked together to provide 3 images as stated before for Walmsburger Werder in 2010 and 2011, as well as for Wehninger Werder in 2011. The effect of this filter on the image sharpness is shown in Figure 5. The De-Grandi image looks non-pixilated, more homogenous and similar to the optical ones other than the Lee filter images.

\subsection{Image Classification}

Due to the limitation of the possible polarizations $(\mathrm{HH}$, VV) of the TerraSAR-X sensor data, using only unique date images for establishing the required agricul- tural classification is unlikely to achieve accurate results. Therefore, multi temporal approaches were used to increase the classification accuracy through enabling mapping of temporal changes due to plant growth. The classifications were generated by stacking the different available imagery into three images representing the different acquired dates with the available polarization covering the crop period for both study areas. Maximum likelihood classifier was used to identify the cultivated crops using ERDAS Imagine. The classifications were produced based on several attempts using all available acquired dates, besides attempts representing partial periods, in addition to attempts using single polarization. Three crop calendar classifications were produced using the Model Maker of ERDAS imagine to combine the crops together according to their cultivation period for both study areas in 2010 and 2011.

\subsection{Accuracy Assessment of the Classifications}

The produced classifications were analyzed using the spatial module under ARCGIS to estimate the distribution of the classification with respect to the crop distribution within the test fields. The distribution results were exported into dBase format and thus transformed into excel files to calculate accuracy assessment parameters including the user accuracy for each crop, the producer accuracy for each crop, the Kappa index for the whole classification, and the total accuracy for the entire classification [26]. The results of the produced classifications are presented and explained below.

\section{Results and Discussions}

For each filter, 30 classifications were generated for the pilot area around the Walmsburger Werder in 2010, as well as 38 classifications in 2011, in addition to 32 classifications around the Wehninger Werder in 2011. The produced classifications were assessed and the external producer accuracy for each crop over the testing area and the total accuracy were estimated. Tables 3 and 4 present the accuracy assessment results for fields around the Walmsburger Werder in 2010 and 2011 respectively,
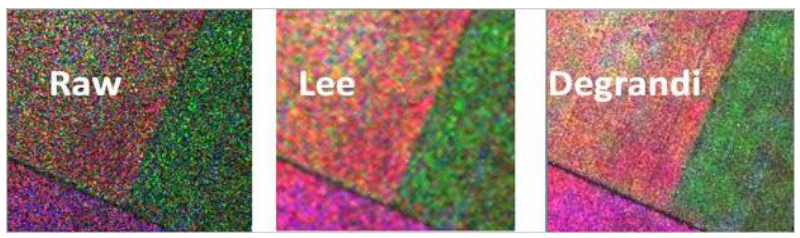

Figure 5. Effect of using Lee and De Grandi filters on removing the speckle noises.

Table 3. External producer accuracy for each crop and the total accuracy at Walmsburger Werder using De Grandi and Lee filter images in year 2010.

\begin{tabular}{|c|c|c|c|c|c|c|c|c|c|c|c|c|c|c|c|c|c|c|c|}
\hline \multirow{3}{*}{ 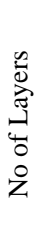 } & \multirow[b]{3}{*}{ Period } & \multicolumn{18}{|c|}{ External Producer Accuracy \% } \\
\hline & & \multicolumn{9}{|c|}{ De Grandi Filter image } & \multicolumn{9}{|c|}{ Lee Filter image } \\
\hline & & $\begin{array}{l}\frac{n}{\widetilde{J}} \\
\text { Uूँ }\end{array}$ & 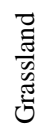 & 芯 & $\begin{array}{l}0 \\
\stackrel{\pi}{0} \\
0\end{array}$ & 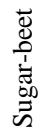 & 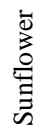 & 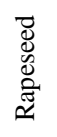 & 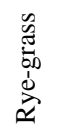 & స్ّ & 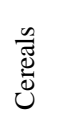 & 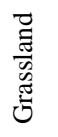 & $\underset{\Sigma}{\stackrel{N}{\pi}}$ & 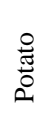 & 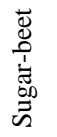 & 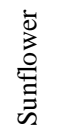 & 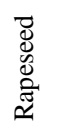 & 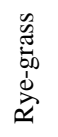 & స్ㅠㅁ \\
\hline \multirow{2}{*}{6} & 30 Apr-27 jul & 67 & 79 & 36 & 96 & 60 & & 81 & & 73 & 61 & 85 & 38 & 90 & 51 & & 82 & & 71 \\
\hline & 5 Jul-18 Aug & 55 & 78 & 51 & 97 & 59 & & 77 & & 67 & 48 & 79 & 41 & 88 & 54 & & 74 & & 62 \\
\hline \multirow{2}{*}{8} & 30 Apr-18 Aug & 63 & 77 & 53 & 98 & 62 & & 84 & & 74 & 60 & 87 & 47 & 94 & 55 & & 82 & & 71 \\
\hline & 5 Jul-9 Sep & 66 & 69 & 57 & 87 & 59 & & 81 & & 73 & 58 & 84 & 43 & 76 & 56 & & 74 & & 65 \\
\hline \multirow{2}{*}{10} & 30 Apr-9 Sep & 73 & 70 & 59 & 92 & 60 & & 88 & & 79 & 65 & 90 & 48 & 92 & 57 & & 82 & & 73 \\
\hline & 5 Jul-23 Oct & 78 & 73 & 59 & 90 & 73 & & 88 & & 82 & 69 & 91 & 48 & 81 & 57 & & 75 & & 71 \\
\hline \multirow{2}{*}{12} & 30 Apr-23 Oct & 82 & 72 & 62 & 98 & 73 & & 93 & & 86 & 71 & 92 & 52 & 94 & 58 & & 83 & & 77 \\
\hline & 5 Jul-14 Nov & 78 & 71 & 60 & 91 & 74 & & 92 & & 83 & 69 & 92 & 50 & 82 & 57 & & 78 & & 73 \\
\hline \multirow[t]{2}{*}{14} & 30 Apr-14 Nov & 83 & 71 & 64 & 98 & 76 & & 96 & & 88 & 72 & 93 & 52 & 95 & 58 & & 85 & & 78 \\
\hline & CAL & 74 & 78 & 62 & 94 & 76 & & 89 & & 81 & 70 & 94 & 52 & 94 & 60 & & 79 & & 75 \\
\hline
\end{tabular}


Table 4. External producer accuracy for each crop and the total accuracy at Walmsburger Werder using De Grandi and Lee filter images in year 2011.

\begin{tabular}{|c|c|c|c|c|c|c|c|c|c|c|c|c|c|c|c|c|c|c|c|}
\hline \multirow{3}{*}{ 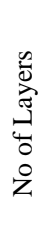 } & \multirow[b]{3}{*}{ Period } & \multicolumn{18}{|c|}{ External Producer Accuracy \% } \\
\hline & & \multicolumn{9}{|c|}{ De Grandi Filter image } & \multicolumn{9}{|c|}{ Lee Filter image } \\
\hline & & 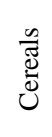 & 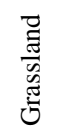 & $\underset{\stackrel{\mathbb{N}}{\pi}}{\stackrel{\pi}{\pi}}$ & 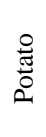 & 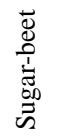 & 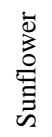 & 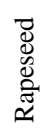 & 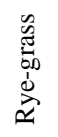 & స్త్ర & 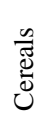 & 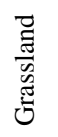 & $\underset{\Sigma}{\stackrel{N}{\pi}}$ & $\begin{array}{l}0 \\
\text { 苟 } \\
0\end{array}$ & 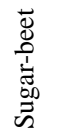 & 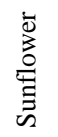 & 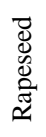 & 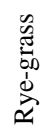 & స్ㅠㅁ \\
\hline \multirow{3}{*}{8} & 17 Apr-05 Aug & 87 & 84 & 80 & 78 & 97 & 61 & 94 & 96 & 86 & 73 & 74 & 73 & 67 & 88 & 46 & 91 & 92 & 75 \\
\hline & 31 May-27 Aug & 87 & 82 & 83 & 77 & 85 & 51 & 73 & 96 & 85 & 77 & 78 & 72 & 60 & 78 & 22 & 67 & 94 & 76 \\
\hline & 26 Mar-05 Aug & 91 & 87 & 87 & 89 & 95 & 78 & 88 & 96 & 90 & 80 & 81 & 74 & 70 & 91 & 63 & 90 & 94 & 80 \\
\hline \multirow[t]{3}{*}{10} & 17 Apr-27 Aug & 91 & 86 & 87 & 91 & 97 & 73 & 87 & 96 & 89 & 80 & 81 & 75 & 71 & 90 & 55 & 90 & 94 & 80 \\
\hline & 31 May-18 Sep & 91 & 83 & 88 & 92 & 35 & 45 & 74 & 97 & 87 & 82 & 81 & 76 & 81 & 61 & 24 & 67 & 96 & 80 \\
\hline & 26 Mar-27 Aug & 91 & 87 & 87 & 89 & 95 & 78 & 88 & 96 & 90 & 80 & 81 & 74 & 70 & 91 & 63 & 90 & 94 & 80 \\
\hline \multirow[t]{3}{*}{12} & 17 Apr-18 Sep & 93 & 87 & 91 & 95 & 43 & 67 & 86 & 96 & 91 & 84 & 83 & 79 & 87 & 78 & 54 & 89 & 95 & 84 \\
\hline & 31 May-10 Oct & 95 & 84 & 86 & 89 & 37 & 50 & 78 & 97 & 89 & 87 & 83 & 76 & 78 & 59 & 36 & 70 & 96 & 83 \\
\hline & 26 Mar-18 Sep & 93 & 88 & 91 & 91 & 42 & 72 & 88 & 96 & 91 & 84 & 83 & 79 & 84 & 78 & 62 & 89 & 95 & 83 \\
\hline \multirow[t]{2}{*}{14} & 17 Apr-10 Oct & 95 & 87 & 89 & 94 & 40 & 69 & 86 & 96 & 91 & 89 & 85 & 80 & 84 & 71 & 60 & 90 & 95 & 87 \\
\hline & 31 May-01 Nov & 94 & 84 & 89 & 92 & 38 & 57 & 84 & 93 & 90 & 85 & 83 & 78 & 81 & 44 & 41 & 74 & 94 & 83 \\
\hline \multirow{2}{*}{16} & 26 Mar-10 Oct & 95 & 89 & 89 & 91 & 40 & 74 & 88 & 96 & 92 & 87 & 81 & 72 & 78 & 72 & 56 & 86 & 94 & 83 \\
\hline & 17 Apr-01 Nov & 95 & 87 & 91 & 93 & 39 & 70 & 89 & 93 & 91 & 88 & 85 & 81 & 85 & 55 & 63 & 91 & 94 & 86 \\
\hline 18 & 26 Mar-01 Nov & 95 & 88 & 91 & 91 & 39 & 75 & 90 & 93 & 92 & 88 & 85 & 80 & 83 & 53 & 69 & 91 & 94 & 86 \\
\hline \multirow{2}{*}{8} & 26 Mar-10 Oct_HH & 92 & 87 & 84 & 88 & 39 & 73 & 88 & 97 & 89 & 80 & 80 & 73 & 69 & 68 & 61 & 84 & 95 & 79 \\
\hline & 26 Mar-10 Oct_VV & 94 & 85 & 86 & 91 & 42 & 73 & 85 & 96 & 90 & 87 & 81 & 72 & 78 & 72 & 56 & 86 & 94 & 83 \\
\hline \multirow{3}{*}{9} & 26 Mar-01 Nov_HH & 90 & 87 & 86 & 88 & 39 & 75 & 91 & 93 & 88 & 77 & 82 & 74 & 71 & 56 & 64 & 86 & 94 & 78 \\
\hline & 26 Mar-01 Nov_VV & 94 & 85 & 88 & 92 & 39 & 76 & 87 & 93 & 90 & 85 & 81 & 73 & 78 & 51 & 60 & 87 & 93 & 82 \\
\hline & CAL & 97 & 89 & 90 & 94 & 40 & 73 & 93 & 95 & 93 & 90 & 80 & 81 & 89 & 77 & 61 & 92 & 93 & 86 \\
\hline
\end{tabular}

while Table 5 presents the results for the agricultural fields around the Wehninger Werder in 2011. The classification according to crop calendar was called CAL.

According to Tables 3-5, using De Grandi filter leads to about $10 \%$ better classification results than using the Lee filtered images except for grasslands in 2010 where Lee filter has better producer accuracy by about $15 \%$ as shown in Figure 6. The best result is attained for potato fields cultivated around the Wehninger Werder, where its external producer accuracy is $100 \%$. On the other hand, the worst result is gained for maize fields around Walmsburger in 2010 with only 36\%. Moreover, the sugar-beet root cultivated around Walmsburger Werder in 2011 has only 40\% external producer accuracy. The achieved producer accuracy result shows that using more layers improved the classification total accuracy for both the Walmsburger and Wehninger Werder. However, it is not applicable at the crop level, as rye-grass fields around
Wehninger Werder attain less producer accuracy when more images are used, although using only VV polarization leads to higher classification accuracy. Better results were achieved for the other crops using both polarizations for both study areas and even for the rye-grass fields around Walmsburger Werder. On the other hand, sugar-beet root covering the fields from March till October around Walmsburger Werder has less producer accuracy when more layers are used contradicting the crop calendar. In 2011, the classification result around Walmsburger Werder is enhanced by over $10 \%$ for the total producer accuracy with respect to 2010, as well as about $20 \%$ in case of cereal fields, and over 30\% for maize as shown in Figure 7.

Generally, the classifications produced according to the crop calendar have higher total producer accuracy than using all images with the exception of sugar-beet root as stated above. For the arable land around Walmsburger 


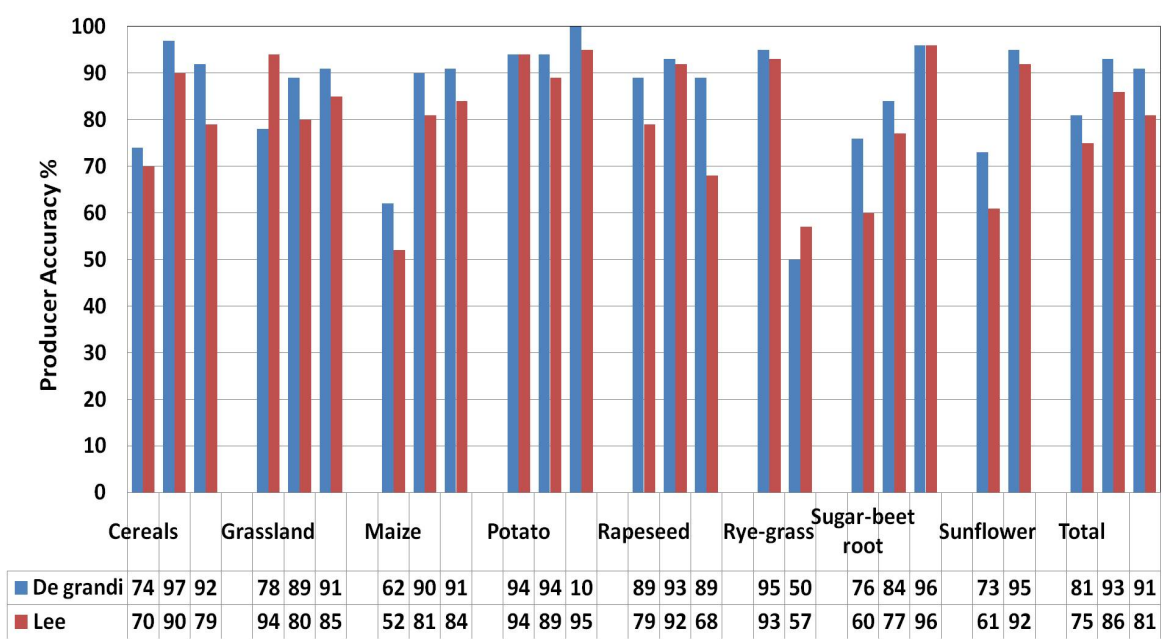

Figure 6. Summary of the producer accuracy for the different crops and the total accuracy using both Lee and De Grandi filtered imagery according to the crop calendar.

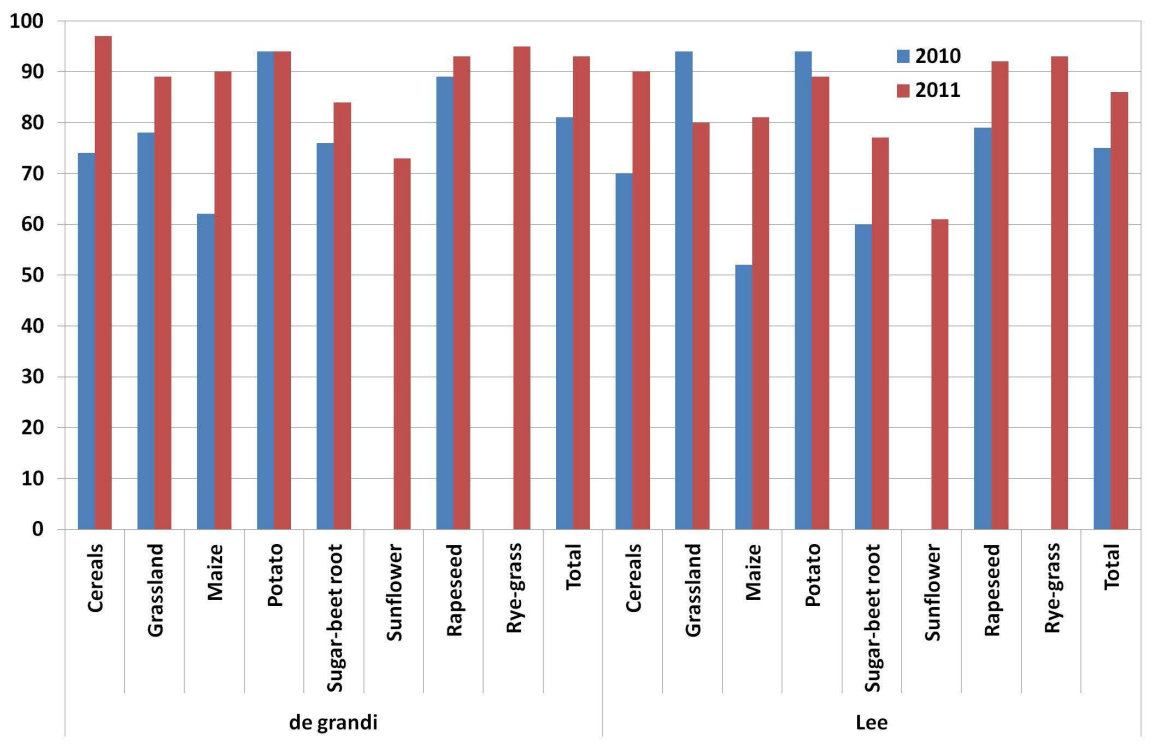

Figure 7. Summary of the producer accuracy for the different crops and the total accuracy using both Lee and De Grandi filtered imagery according to the crop calendar around Walmsburger Werder in year 2010 and 2011.

Werder, using images for the period from March onwards usually leads to higher producer accuracies than using images from April or May except for maize, as it is sown only late April or at the beginning of May. Thus, availability of frequent images covering most of the crop calendar period results in increasing the classification accuracies. This indicates that the classification results for the Wehninger Werder can be enhanced by an image series taken before June.

In year 2010, the use of images from April improves the producer accuracy for cereals, rapeseeds, and potato fields. Yet, using the images starting from July improves the classification results for maize and sugar-beet root fields. Missing an image in July for the fields cultivated around the Walmsburger Werder in 2011 and thus having a gap of 44 days instead of 22 days, caused slightly lower producer accuracies compared to the Wehninger Werder where a complete series of images from June until November had been available. Moreover, the increase of the gap to about 66 days decreased the classification producer accuracy by about $10 \%$ in case of year 2010, particularly because these 66 days fell into the growing season for most of the plants. The external producer accuracies over the test fields were high. Hence, the classification for the remote non accessible area can be trusted also.

\section{Concluding Remarks}

Image filtering was essential for enhancing crop classification results. The multi temporal filter De Grandi enhanced the producer accuracy by about $10 \%$ compared to 
Table 5. External producer accuracy for each crop and the total accuracy at Wehninger Werder using De Grandi and Lee filter images.

\begin{tabular}{|c|c|c|c|c|c|c|c|c|c|c|c|c|c|c|c|c|c|c|c|}
\hline \multirow{3}{*}{ 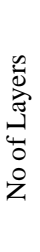 } & \multirow[b]{3}{*}{ Period } & \multicolumn{18}{|c|}{ External Producer Accuracy \% } \\
\hline & & \multicolumn{10}{|c|}{ De Grandi Filter image } & \multicolumn{8}{|c|}{ Lee Filter image } \\
\hline & & $\frac{\mathscr{\sigma}}{\mathbb{Z}}$ & 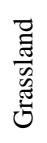 & 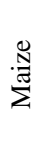 & $\begin{array}{l}\stackrel{0}{\pi} \\
\text { 윰 }\end{array}$ & 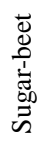 & 岂 & 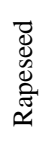 & 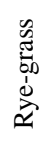 & 预 & $\frac{\mathscr{\Xi}}{\circlearrowright}$ & 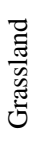 & : & 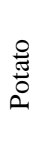 & 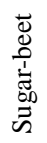 & 竞 & 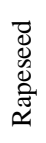 & 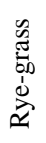 & 矛 \\
\hline 6 & 28Jun-11Aug & 55 & 80 & 69 & 45 & 82 & 73 & 57 & 58 & 66 & 79 & 85 & 84 & 95 & 96 & 92 & 68 & 57 & 81 \\
\hline \multirow{2}{*}{8} & 06Jun-_11Aug & 92 & 91 & 91 & 100 & 96 & 95 & 89 & 50 & 91 & 57 & 82 & 67 & 71 & 87 & 59 & 50 & 53 & 66 \\
\hline & 28Jun-02Sep & 64 & 83 & 78 & 88 & 81 & 82 & 57 & 61 & 72 & 49 & 81 & 62 & 71 & 91 & 66 & 43 & 53 & 61 \\
\hline \multirow{2}{*}{10} & 06Jun-_02Sep & 77 & 88 & 86 & 97 & 91 & 68 & 72 & 62 & 82 & 61 & 84 & 74 & 84 & 91 & 67 & 51 & 56 & 70 \\
\hline & 28Jun-24Sep & 68 & 85 & 78 & 98 & 89 & 81 & 60 & 47 & 74 & 55 & 84 & 70 & 85 & 96 & 65 & 46 & 54 & 66 \\
\hline \multirow{2}{*}{12} & 06Jun-24Sep & 81 & 90 & 87 & 99 & 94 & 71 & 75 & 47 & 84 & 66 & 87 & 79 & 91 & 96 & 66 & 53 & 55 & 74 \\
\hline & 28Jun-17Oct & 83 & 89 & 85 & 98 & 90 & 85 & 82 & 43 & 85 & 68 & 90 & 74 & 83 & 96 & 70 & 63 & 56 & 76 \\
\hline \multirow{2}{*}{14} & 06Jun-17Oct & 91 & 92 & 90 & 99 & 94 & 77 & 90 & 44 & 91 & 78 & 91 & 81 & 90 & 96 & 72 & 71 & 58 & 82 \\
\hline & 28Jun-07Nov & 84 & 92 & 89 & 99 & 96 & 97 & 87 & 47 & 88 & 69 & 91 & 78 & 87 & 97 & 91 & 73 & 80 & 79 \\
\hline 16 & 06Jun-07Nov & 93 & 93 & 92 & 100 & 98 & 95 & 92 & 48 & 93 & 79 & 92 & 82 & 94 & 97 & 91 & 79 & 80 & 84 \\
\hline \multirow{2}{*}{7} & 06Jun-17Oct_HH & 74 & 87 & 81 & 96 & 89 & 55 & 74 & 13 & 79 & 61 & 86 & 73 & 76 & 94 & 56 & 55 & 30 & 70 \\
\hline & 06Jun-17Oct_VV & 89 & 89 & 81 & 98 & 92 & 85 & 86 & 86 & 87 & 74 & 89 & 71 & 87 & 95 & 62 & 60 & 70 & 77 \\
\hline \multirow{2}{*}{8} & 06Jun-07Nov_HH & 77 & 90 & 84 & 98 & 94 & 87 & 82 & 28 & 83 & 62 & 87 & 74 & 85 & 96 & 85 & 64 & 64 & 73 \\
\hline & CAL & 92 & 91 & 91 & 100 & 96 & 95 & 89 & 50 & 91 & 79 & 85 & 84 & 95 & 96 & 92 & 68 & 57 & 81 \\
\hline
\end{tabular}

the Lee filter. Using large ground truth data of over 150 fields in 2011 enabled better classification accuracy than using just 50 fields as in 2010. Using sequence images covering the growing season usually improved the classification results. Moreover, missing images within the cultivation period decreased the attained classification producer accuracy. Furthermore, using dual polarization images enabled higher classification producer accuracy than single polarization sets.

As mentioned previously, the produced classifications according to the crop calendar achieved more significant results than using all images for most of the crops except for rye-grass around the Wehninger Werder and sugarbeet root around the Walmsburger Werder. Greatest producer accuracy was achieved for the rye-grass fields around the Wehninger Werder if VV polarization was used exclusively. The sugar-beet root fields around Walmsburger Werder achieved the highest producer accuracy using the image series ranging from March until the end of August. Hence, by combining the set used for producing the classification according to the crop calendar with the best classifications for sugar-beet root and rye-grass, classification accuracy will be enhanced.

Finally, it is recommended to use frequent images in dual polarization covering the whole cultivation period. The crops must be classified according to their cultivation period and then modeled together to simulate reality. This study was conducted on accessible fields. Over 50\% of these fields were used as testing fields for evaluating the external producer accuracy for the generated classifications. The classification result showed high external producer accuracy. Thus this method can be applied to other remote areas. It is recommended to usually monitor the whole Biosphere Reserve using TerraSAR-X images to prevent any environmental problems due to misuse of these protected areas..

\section{Acknowledgements}

We are greatly indepted to the administration of the Biosphere Reserve "Niedersächsische Elbtalaue" (Lower Saxonian Elbe Valley) and the German Aerospace Centre (Deutsches Zentrum für Luft-und Raumfahrt, DLR) for providing the satellite images for this study. We highly 
acknowledge the support of this research by a $\mathrm{PhD}$ graduate scholarship of LEUPHANA University Lueneburg awarded to Farghaly.

\section{REFERENCES}

[1] U. Brämick, F. Fladung and P. Doering-Arjes, “Aalmanagementplan-Flussgebietsgemeinschaft Elbe,” Institut für Binnenfischerei, 2008.

http://www.portal-fischerei.de/fileadmin/redaktion/dokum ente/fischerei/Bund/Bestandsmanagement/Flussgebietsge meinschaftElbe.pdf

[2] G. Puhlmann and S. Reinhardt, "Partnerships between River Biosphere Reserves,” UNESCO Publications, 2007, pp. 75-77.

[3] W. Härdtle, B. Redecker, T. Assmann and H. Meyer, "Vegetation Responses to Environmental Conditions in Floodplain Grasslands: Prerequisites for Preserving Plant Species Diversity,” Basic and Applied Ecology, Vol. 7, No. 3, 2006, pp. 280-288. http://dx.doi.org/10.1016/j.baae.2005.09.003

[4] R. N. Lubowski, S. Bucholtz, R. Claassen, M. J. Roberts, J. C. Cooper, A. Gueorguieva and R. Johansson, "Environmental Effects of Agricultural Land-Use Change," United States Department of Agriculture (USDA), Economic Research Service, Economic Research Report No. 25, 2006.

http://ageconsearch.umn.edu/bitstream/33591/1/er060025 .pdf

[5] F. Krüger and A. Gröngröft, "The Difficult Assessment of Heavy Metal Contamination of Soils and Plants in Elbe River Floodplains," Acta Hydrochimica et Hydrobiologic, Vol. 31, No. 4-5, 2003, pp. 436-443.

[6] B. Urban, "River Elbe Ecology-Contributions to a Large Scale Environmental Project," In: R. Ramesh and S. Ramachandran, Eds., Coastal Urban Environments, Capital Publishing Company, New Delhi, 2003, pp. 67-88.

[7] G. Tevi and A. Tevi, "Remote Sensing and GIS Techniques for Assessment of the Soil Water Content in Order to Improve Agricultural Practice and Reduce the Negative Impact on Groundwater," Water Science \& Technology Journal, Vol. 66, No. 3, 2012, pp. 580-587. http://dx.doi.org/10.2166/wst.2012.209

[8] B. Urban, F. Krüger, T. Weniger, J. Prüter, T. Keienburg, F. Lang and M. Graf, "Auenböden der Elbe als Archiv für die Stoffdynamik im Einzugsgebiet," Proceedings Deutsche Bodenkundliche Gesellschaft DBG Exkursionsführer, Oldenburg/Berlin, 2011, pp. 42-59.

[9] C. Sehnert, S. Huang and K. Lindenschmidt, "Quantifying Structural Uncertainty due to Discretisation Resolution and Dimensionality in a Hydrodynamic Polder Model," Journal of Hydroinformatics, Vol. 11, No. 1, pp. 19-30.

[10] A. E. Mynett and Z. Vojinovic, "Hydroinformatics in Multi-Colours-Part Red: Urban Flood and Disaster Management," Journal of Hydroinformatics, Vol. 11, No. 3-4, 2009, pp. 166-179.

[11] B. Koppe, B. Llacay and G. Peffer, "RAMWASS Decision Support System (DSS) for the Risk Assessment of
Water-Sediment-Soil Systems-Application of a DSS Prototype to a Test Site in the Lower Part of the Elbe River Valley, Germany," Proceedings of the European Conference on Flood Risk Management Research into Practice (FLOODrisk), CRC Press, London, 2008.

[12] E. M. Makhanya, S. E. Piper and M. Townsend, "Mapping Rural Land Use in Selected Subsistence Farming Areas of South Africa Using Remote Sensing Products," Proceedings IntArchPhRS. Band XXIX, Part B 7, Washington, D.C., 1992, pp. 675-682.

[13] S. J. Purkis and V. V. Klemas, "Remote Sensing and Global Environmental Change,” Wiley-Blackwell, Chichester, West Sussex, 2011.

[14] D. Farghaly, B. Urban, P. Lohmann and E. Elba, "Differentiation and Extend of Aquatic Weeds over Lake Kyoga, Uganda by Multiple Remote Sensing Technology,” Proceedings 4th TerraSAR-X Science Team Meeting, DLR-Oberpfaffenhofen, 2011.

http://sss.terrasar-x.dlr.de/papers_sci_meet_4/oral/LAN04 99_Farghaly.pdf

[15] P. Lohmann, U. Soergel, M. Tavakkoli and D. Farghaly, "Multi-Temporal Classification for Crop Discrimination Using TerraSAR-X Spotlight Images," Proceedings IntArchPhRS (38), Part 1-4-7/WS, Hannover, 6 S., CD, 2009.

http://www.isprs.org/proceedings/XXXVIII/1_4_7-W5/p aper/Lohmann-129.pdf

[16] M. Tavakkoli, "Multi-Temporal Classification of Crops Using ENVISAT ASAR Data,” Ph.D. Dissertation, Leibniz University of Hannover, 2011.

[17] M. Tavakkoli, P. Lohmann and U. Soergel, "Monitoring Agricultural Activities Using Multi-Temporal ASAR ENVISAT Data," Proceedings IntArchPhRS, Band XXXVII, Teil B 7-2, Peking, 2008, pp. 735-742

[18] J. A. Richards, "Remote Sensing with Imaging Radar," Springer, Australia, 2009. http://dx.doi.org/10.1007/978-3-642-02020-9

[19] Landwirtschaftskammer Niedersachsen, "EndberichtMachbarkeitsuntersuchung zur Monovergärung von Grassilagen schadstoffkontaminierter Standorte aus Deichvorland der Elbe,” 2011.

http://www.lwk-niedersachsen.de/index.cfm/portal/6/nav/ 203/article/14596.html

[20] I. Leyer, “Auengrünland der Mittelelbe-Niederung," Vegetationskundliche und-ökologische Untersuchungen in der rezenten Aue, der Altaue und am Auenrand der Elbe, J. Cramer, Borntraeger, Berlin, 2002.

[21] P. Lohmann, U. Soergel and D. Farghaly, “Classification of Agricultural Sites Using Time-Series of High Resolution Dual-Polarisation TerraSAR-X Spotlight Images," Proceedings 29th EARSeL Symposium-Imaging Europe, Chania, 2009.

http://www.ipi.uni-hannover.de/uploads/tx tkpublikation en/2009_lohmann_Paper_Earsel_TSX.pdf

[22] M. Mansourpour, M. A. Rajabi and J. A. R. Blais, "Effects and Performance of Speckle Noise Reduction Filters on Active Radar and SAR Images," Proceedings IntArchPhRS, Band XXXVI 1/ W41, Ankara, 2006. http://www.isprs.org/proceedings/XXXVI/1-W41/makale 
ler/Rajabi_Specle_Noise.pdf

[23] L. Gagnon, "Wavelet Filtering of Speckle Noise-Some Numerical Results," Proceedings 12th Conference on Vision Interface (VI’99) Trois-Rivières, Québec, 1999, pp. 336-343.

[24] J. Lee, T. L. Ainsworth and K. Chen, "Speckle Filtering of Dual-Polarization and Polarimetric Sar Data Based on Improved Sigma Filter,” Proceedings IGARSS, 2008.
[25] G. F. De Grandi, M. Leysen, J. S. Lee and D. Schuler, "Radar Reflectivity Estimation Using Multiplicative SAR Scenes of the Same Target: Technique and Applications," Proceedings IGARSS, 1997.

[26] D. G. Rossiter, "Statistical Methods for Accuracy Assessment of Classified Thematic Maps," 2004. http://www.itc.nl/ rossiter/teach/R/R_ac.pdf 